\title{
Retracted: Free Radical Production in Immune Cell Systems Induced by Ti, Ti6Al4V and SS Assessed by Chemiluminescence Probe Pholasin Assay
}

\author{
International Journal of Biomaterials
}

Received 5 August 2013; Accepted 5 August 2013

Copyright (C) 2013 International Journal of Biomaterials. This is an open access article distributed under the Creative Commons Attribution License, which permits unrestricted use, distribution, and reproduction in any medium, provided the original work is properly cited.

The article titled "Free Radical Production in Immune Cell Systems Induced by Ti, Ti6Al4V and SS Assessed by Chemiluminescence Probe Pholasin Assay" [1], published in International Journal of Biomaterials, has been retracted as it was submitted for publication without the knowledge and approval of the coauthor John Hunt.

\section{References}

[1] S. C. P. Cachinho and F. Pu, "Free radical production in immune cell systems induced by Ti, Ti6Al4V and SS assessed by chemiluminescence probe pholasin assay," International Journal of Biomaterials, vol. 2012, Article ID 380845, 7 pages, 2012. 